The creation view of opportunities at the base of the pyramid

Corresponding Author: Dr. Misagh Tasavori, Essex Business School, University of Essex,

Elmer Approach, Southend on Sea, Essex, SS1 1LW, United Kingdom

$\mathrm{T}+44(0) 1702328399$

$\mathrm{F}+44(0) 1702328385$

Email: Tasavori@essex.ac.uk

Dr. Reza Zaefarian, Faculty of Entrepreneurship, University of Tehran,

16th Street, North Karegar Avenue, Tehran, Iran

Tel: +98 (21) 88225000

Email: rzaefarian@ut.ac.ir

Prof. Pervez Nasim Ghauri

Department of Management

King's College London

150 Stamford Street

London SE1 9NH, UK

Tel: +44 (0) 2078484122

Email: pervez.ghauri@kcl.ac.uk 


\section{The creation view of opportunities at the base of the pyramid}

This research aims to understand how multinational corporations (MNCs) enter the base of the pyramid (BoP) by adopting the creation view of opportunities. We employ actornetwork theory and explore the key actors, the process and the opportunity development that enable MNCs to tackle the relative poverty of the BoP market. Our qualitative exploratory case study illustrates that at the BoP, MNCs have to involve beneficiary stakeholders such as non-governmental organisations (NGOs) and BoP communities. In this process, they should be open to modifying their business model continuously to build awareness about the product among the poor and ensure affordability, availability and acceptability. At the BoP, opportunities do not exist in the external environment and they should be developed by identifying and addressing the real needs of the poor, enhancing their quality of life and being patient about earning a profit. This research contributes to the entrepreneurship literature by expanding the creation perspective of opportunities, and provides implications for the managers of companies targeting the BoP market.

Key words: creation view of opportunity; base of the pyramid; BoP; actor-network theory; India; 


\section{Introduction}

Opportunities are critical to the survival, profitability and growth of corporations (e.g., Verbeke, Chrisman, and Yuan 2007, Halme, Lindeman, and Linna 2012, Webb et al. 2010). An opportunity is a set of environmental conditions that leads to the introduction of a new product/service in the market (Dutta and Crossan 2005, 426). Identifying new opportunities globally and turning them into income streams have become critical for multinational corporations (MNCs) as they are faced with intense competition and saturated markets in developed countries (London and Hart 2004). One of the markets that has captured the attention of MNCs is the Base of the Pyramid (BoP) (Schuster and Holtbrügge 2012, Hart 2005). The BoP represents around $70 \%$ of the world's population who live in relative poverty and have been ignored by MNCs to date because of their disadvantaged condition (Prahalad 2010).

In this research, we aim to understand how MNCs can enter the BoP. We adopt a creation perspective of opportunities, which builds on an interpretive or social construction ontology and posits that opportunities do not exist independently but are formed through the interaction of an entrepreneurial team with the external environment (Baker and Nelson 2005, Korsgaard 2011, Steyaert 2007). We employ actor-network theory (ANT) (Korsgaard 2011) and attempt to explore the following: (a) Who are the key actors that should be involved? (b) What is the nature of the entrepreneurship process? and (c) How are opportunities developed at the BoP?

This research makes several contributions. First, although there is a proliferation of research about opportunities in small and medium-sized enterprises (Sanz-Velasco 2006, Williams and Williams 2012), there are fewer studies that have focused on the concept of 
opportunity in large and established corporations (Zahra 1996, Kellermanns and Eddleston 2006, Ghauri, Hadjikhani, and Johanson 2005), especially at the BoP (Prahalad 2010). The findings of this research bridge this gap and shed light on how MNCs can successfully enter the BoP market, which can present a new avenue for their future growth (Prahalad 2010, London and Hart 2004). Second, while the opportunity discovery perspective has been the dominant view in the entrepreneurship literature (Kirzner 1997, 1973, Shane and Venkataraman 2000), this research reveals the necessity of pursuing an alternative approach at the BoP. It thus adds to the growing literature on the creation perspective of opportunities and provides empirical examples supporting the ANT-informed interpretation of opportunities (Korsgaard 2011).

In the rest of this paper, we first define the context of the BoP, review the ANT and explain the research methodology. Then, the findings of the paper are discussed. The paper concludes with the theoretical and managerial implications, and an explanation of the research limitations and future research avenues.

\section{The context of the base of the pyramid}

The BoP is usually used to refer to the approximately 4 billion people globally whose earnings are below the poverty line (Prahalad 2010). Statistics illustrate that 2.6 billion of these people earn less than two dollars a day and 1.4 billion earn between two and eight dollars daily (Schuster and Holtbrügge 2012). Political instability, and a lack of access to technologies and employment opportunities have prevented these people from finding their own way out of poverty (Hammond et al. 2007, UNDP 2008). In addition, the majority of these people are 
illiterate and live in scattered rural areas where the infrastructure is poorer and there are fewer facilities (Hammond et al. 2007, The World Bank 2008).

Anderson and Billou (2007) have highlighted that because of the nature of the BoP, if companies want to enter this market, they have to consider the 4As of awareness, acceptability, affordability and availability. In other words, MNCs should make sure that poor people are aware of the existence of their product and the advantages that it can offer, that they can afford to purchase the product, and that the product is available in their village if they decide to buy it.

\section{Actor-network theory (ANT)}

The ANT is employed in this research to discuss the creation perspective of opportunity. As Korsgaard (2011) explains, the ANT emanates from semiotics, where the meaning of a word is dependent on its relation to other words (Law 1999). Therefore, according to the ANT perspective, the identity of any object, whether human or non-human, is dependent on its relations with others. The ANT is grounded on constructivist assumptions (Burr 2003) which perceive the social reality as being objective and the result of collective constructive endeavours. However, the ANT goes beyond the constructivism forms and views human and non-human as mutually constitutive. Korsgaard $(2011,665)$ states that "for ANT, the continuous construction of reality is accomplished as much through materials and material practices as through mental or discursive activities. In that sense it maintains a form of realism as extra-mental or extradiscursive elements are not constructed through mental or discursive operations".

The ANT is based on the ontology of becoming (Chia 1995), in which entrepreneurs, firms and markets are created as a result of exchange. In the ANT approach, the focus of the 
analysis is on the dynamic becoming of entities (Van De Ven 2007). Similarly, in the creation perspective, the ANT shows how opportunity is a product of the involvement of several actors and not the initial point of the process.

This theoretical perspective is built upon three elements of agency, process and the opportunity development (Korsgaard 2011) (see Figure 1), which are explained in the following section.

$$
\text { ***Insert Figure } 1 \text { about here*** }
$$

\subsection{Agency}

In the ANT interpretation of the creation view, an agent is defined as " 'anything' that modifies a state of affairs by making a difference" (Latour 2005, 71). Therefore, the entrepreneurial process does not have to focus on the initial person but can include more actors such as customers, advisors or suppliers, who contribute to the process. This is similar to the suggestion of those scholars who argue that entrepreneurship is a collective action and unfolds through interaction between different actors in order to achieve a new commercial goal (Johannisson 1998, Johannisson and Nilsson 1989, Holmquist 2003, Lindgren and Packendorff 2003, Johannisson 2011).

Latour's (2005) definition of an agent also allows the consideration of other types of actors, both human and non-human, that play a fundamental role in the entrepreneurial process. In addition, the ANT shifts the attention away from the sole entrepreneur to other agents and the 
network in which the entrepreneur is embedded (Gaddefors 2005, Johannisson, Ramírez-Pasillas, and Karlsson 2002). In the ANT perspective, opportunities are created 'in here' rather than being viewed as pre-existing 'out there'. It is through interaction that the actor (human or non-human) and the opportunity come into existence. According to Korsgaard (2011, 670), "the question is thus not how structure and agent interact, but how a particular structure and agency constellation (or actor-network) has come to be".

The creation perspective of opportunity thus allows the inclusion of the social and relational network of the entrepreneur (Fletcher 2006, Gaddefors 2005, Korsgaard 2011). The role of networks in the entrepreneurial process has been emphasised by several scholars (Anderson and Jack 2002, Ghauri, Hadjikhani, and Johanson 2005, Chabaud et al. 2012). Networks have been found to enable companies to get access to cheaper resources, and even resources that may not be available in markets (Witt 2004, Bhagavatula et al. 2010), to gain valuable information (Tolstoy 2010) and to achieve competitive advantage (Lechner and Dowling 2003, Butler and Hansen 1991).

\subsection{Process}

According to the ANT understanding of the creation view, the three stages of discovery, evaluation and exploitation are not separable; discovery is a continuous process and opens up due to the interaction of agents. Evaluation and exploitation co-exist as a new understanding of the current situation is suggested, accepted or denied. Exploitation is based on agents collaborating to act upon an opportunity (Korsgaard 2011). 
Actors initiate their activities based on their understanding of their abilities, and the nature of opportunities and resources that are at hand (Alvarez and Parker 2009, Baker and Nelson 2005). These initial beliefs about opportunities, resources and abilities are all socially constructed, and may vary among different actors (Mosakowski 1997). Because of the mismatch between these beliefs and reality, actors have to act to see the response from their customers, and then adjust their beliefs and act again (Weick 1979). At the beginning, no one knows what the outcome of the process will be; multiple voices of those who are trying to shape opportunity in different directions are heard. Therefore, the transformation of opportunity is an open-ended process and, as a result, opportunity may be reinvented as users take it and transform it to suit their interests (Akrich, Callon, and Latour 2002, Korsgaard 2011). Fletcher (2007) indicates that the identified sequential order is post hoc based on what makes sense of the phenomenon.

\subsection{Opportunity development}

In the creation perspective, opportunities do not exist in the environment and are endogenously generated by the actors (Wood and McKinley 2010). Entrepreneurial agents are constitutive of the external reality and, as a result, opportunities are created through the entrepreneurial process (Sarason, Dean, and Dillard 2006, Sarason, Dillard, and Dean 2010). According to the advocates of this perspective, opportunities are not fully developed at the beginning of the entrepreneurial process (Sanz-Velasco 2006, Korsgaard 2013). Therefore, when studying the entrepreneurial process, the entire transformational process that opportunities undergo should be taken into account (Latour 1987). The advocates of this view explain that, at the initiation of the 
entrepreneurial process, the actors may have some ideas about how their activities might develop into opportunities, but what the end result will be is not clear (Sarasvathy 2008). As stated by Alvarez, Barney, and Anderson (2013, 308), “opportunities cannot be fully understood until they exist, and they only exist after they are enacted in an iterative process of action and reaction". Thus, the creation process is path dependent (Garud and Karnøe 2001) and it is through actions and reactions that opportunities are enacted and exploited (Weick 1979, Alvarez and Barney 2007).

\section{Research methodology}

\subsection{Research design and data collection}

We adopted a qualitative approach in this research, owing to its exploratory nature (Hair et al. 2007, Gerring 2007) and in order to obtain richer data (Flick 2009). The case study methodology was used as it allows the researcher to examine the setting and understand the inherent dynamics of the case in question (Eisenhardt 1989, Eisenhardt and Graebner 2007, Yin 2009). Several company cases were studied, as multiple cases facilitate replication logic and each case can be employed to confirm/disconfirm the findings from the other cases (Creswell 2007, Ghauri 2004).

This research was conducted in India because a considerable share of the BoP population resides there, and the country has attracted MNCs that are targeting the BoP market (Hammond et al. 2007, Prahalad 2010). Eight MNCs that were offering products/services for low-income people in India and five non-governmental organisations (NGOs) agreed to participate in the 
study. However, for reasons of space, and in order to provide a more in-depth understanding of the initiatives of the MNCs, here we focus on three of them: FMCG Co., Mobiles for All and Home Appliances. It should be mentioned, though, that the presented findings of this research are based on the analysis of all interviewed MNCs.

The companies were selected from a variety of industries serving different BoP markets. Diverse cases allow the researcher to obtain more information than average, similar cases would (Eisenhardt and Graebner 2007). In addition, industry diversity is useful when it comes to generalising findings; for example, in this case, conditions at the $\mathrm{BoP}$ may affect different business activities differently (Schuster and Holtbrügge 2012). Table 1 gives an overview of the company cases and their activities at the BoP.

***Insert Table 1 about here***

Primary data were collected using interviews as they are recommended for exploratory and theory-building studies (Silverman 2010, Ghauri and Gronhaug 2010). An interview guide was developed in the form of a semi-structured interview, including questions based on the reviewed literature (Bryman and Bell 2007).

The insights gained from the companies in India were complemented with interviews of managers from the companies' headquarters. Several senior-level managers were interviewed in each company; the interviewees' job titles included Corporate Sustainability Manager, Sales and 
Marketing Manager, Design Manager, Brand Manager, Project Manager, Rural Manager and Head of Corporate Social Investment. The use of multiple informants mitigates subjective bias and results in a richer and more comprehensive understanding (Eisenhardt and Graebner 2007). After one person in a firm had agreed to participate in the research, he/she was then asked to identify another key respondent involved in the firm's entry into the BoP market. This resulted in 44 interviews in total with the MNCs and NGOs. Fourteen interviews were related to the MNCs whose cases are presented in this research, six people being interviewed from FMCG Co., five from Mobiles for All and three from Home Appliances. The interviews in India were conducted between April and June 2010 by two of the authors and followed up over the phone/Skype on occasions between then and 2011. The interviews lasted between 45 and 90 minutes. They were digitally recorded and transcribed, and the transcripts were sent back to the interviewees for confirmation.

When access was granted, representatives of the NGO partners of the MNCs were also interviewed, including one with the NGO partner of Mobiles for All and nine with the NGO partners of other MNCs whose cases are not presented in this paper. Interviewing representatives of the NGOs enabled us to triangulate the perspective of the MNCs (Gummesson 2003) regarding the creation view of opportunity at the BoP. It should be noted that these NGOs had a long history of working with the BoP people, which also helped us to learn about the perspective of the BoP people. In addition, secondary data including the perspective of NGO partners was used. The key sources of secondary data were company websites, company reports, magazines and journals, videos of presentations by executives and other online sources. 


\subsection{Data analysis}

Data analysis commenced with the entry of the transcribed interview data into NVivo qualitative data analysis software. The data analysis pursued cross-case synthesis and was carried out in two phases: within each company and across companies (Flick 2009, Yin 2014). In the first phase, 'story-telling', all interviews in each company were synthesised and a chronology of events that had taken place in the organisation was developed for subsequent analysis (Eisenhardt 1989). In the second phase, we coded the data provided in each interview, meaning that the statements in the interviews were categorised into themes (codes) that captured the theoretical categories (agency, process, opportunity development) as suggested by Ghauri (2004). Under each theme, we were then open to the sub-themes that emerged in each company case explaining how the MNCs were able to enter the BoP market. We then went through several rounds of reduction and abstraction (Swanborn 2012, Ghauri 2004). During this stage, some sub-themes were merged together. The analysis eventually resulted in the identification of a small number of core categories, which served to tightly integrate all the theoretical concepts into the original evidence. After the within-case analysis had been carried out, cross-case analysis was performed. Here, we attempted to identify whether different cases shared similar themes and whether they could be considered as replications of each other, and to aggregate the findings of the research (Yin 2014). The core themes that were found in the within case analysis and confirmed in crosscase analysis under each category of agency, process and opportunity development are presented in the findings section. It should be mentioned that, although in this paper we are presenting the activities of just three of the MNCs, the analysis was carried out for all interviewed companies. 


\section{Company cases at the BoP}

\subsection{FMCG Co.}

FMCG Co. produces fast-moving consumer goods, including food, beverages, cleaning agents and personal care products. It is an MNC headquartered in Europe and has subsidiaries in more than 100 countries. FMCG Co. in India was formed around 80 years ago and is one of India's biggest producers. In 2005 , the company was faced with saturated markets in the urban areas and wealthy segments of the rural areas of India. Around $76 \%$ of the population in India live in rural areas. However, the majority of them are poor and constrained by their low incomes (Hammond et al. 2007, The World Bank 2008). While the lack of disposable income of the BoP people inhibits them from being considered an opportunity at first glance, FMCG Co. decided to enter this market and develop opportunities there. It started with an analysis of the situation facing the BoP people who earned a very small amount of money every day. It was clear that their limited income would constrain them from paying for the relatively expensive, large-sized products of the firm. In addition, the majority of these people were illiterate, did not have access to TV and lived in rural areas where proper infrastructure such as transportation did not exist. All these conditions hindered the firm's use of its main business model and required it to revisit its existing products, prices, means of promotion and distribution channels. One of the top managers recounted:

'We were already a very strong player in India... we knew that a huge market of consumers lies in rural India and we did not have a business model that could take our products to these consumers.' 
Thus, in order to adapt itself to the limited earning of the BoP, the company changed the size of its products and offered single-serve sachets. This strategy led to lower product prices, which enabled the poor to afford the product and buy enough to meet their daily needs. In addition, the company had to change its promotion strategy as it had previously relied on consumers having access to TV and being literate. In its new strategy, the company started dispatching its marketing team to rural areas to promote its products at village gatherings. It also used the walls in the villages to put up pictorial messages (instead of written ones) informing consumers about its products. In addition to building awareness of the availability of its products, with some of the products the company had to motivate people to use them. For example, it had to educate the poor about the necessity of washing their hands with soap in order to remove germs. Diarrhoea, which is caused by poor sanitation and not using soap, kills a considerable number of children in developing countries, and especially in India (World Bank 2000). To encourage people to wash their hands and reduce the incidence of diarrhoea, the company developed an interesting illustration to show that visibly clean hands may still have germs on them. As explained by one of the brand managers:

'The company representatives rub powders onto people's hands and wash their hands with water. Then, under UV light, they show people that, although they have washed their hands with water and they seem to be clean, there is still a residue from the powder on their hands. Then, these people are asked to wash their hands with soap and look at their hands under the UV light again, which illustrates that the powder residue has now been removed.' 
Another challenge that the company had to deal with was related to the distribution of products in rural areas. To tackle this, the company sought the collaboration of NGOs that were working with poor women and educating them on how to start micro-businesses to improve their lives. Through this collaboration, the company gained access to over 3,500 women. These women lived in dispersed rural areas and many were employed to work as FMCG Co.'s representatives, educating people about the products, and selling and distributing them, even in some of the most remote rural areas. This was a win-win solution in that it offered empowerment opportunities to the poor and improved their earnings, while bringing profitability to the firm.

\subsection{Mobiles for All}

Mobiles for All manufactures mobile devices and develops mobile applications (apps). It is headquartered in Europe, and sells its products in more than 150 countries. A statistical analysis of the market in India showed the company that, while in some of the big cities such as Delhi mobile penetration was around $100 \%$, it was still only $20 \%$ in rural areas. This offered a potentially huge opportunity for the company, provided that it could sell its products in this market. The company's preliminary research revealed that the majority of these people were constrained by the BoP conditions (e.g., low incomes, illiteracy, etc.) and could not afford to buy the existing products of the company. Instead of ignoring this market, Mobiles for All decided to develop solutions so that it could sell its products to the BoP population. First, it started working on its mobile handset to make it suitable for the needs of these people. It simplified the handset and its features so as to offer a basic affordable handset. In the design of the handset, the 
company also had to take into account the specific life circumstances of these people. For example, since the majority of rural people in India are farmers, the company had to consider that the handsets might get dirty and be dropped during farm work. The people's illiteracy also necessitated the development of products that would be easy to use.

Although the handsets were now cheaper, the BoP people were still not keen to spend their limited earnings on them. This led the company to invite NGOs that offered micro-finance to collaborate with it and provide loans to the poor for the purchase of handsets.

Mobiles for All was also asked by some NGOs in India to play a role in addressing social problems such as poverty, widespread disease and illiteracy. Through several meetings with the NGOs and the BoP communities, the company learned how it could contribute towards solving these social problems by developing mobile apps. Through this collaboration, it was able to offer apps that allowed subscribers to receive updates on chosen topics such as market prices, news or weather forecasts, English lessons or help with exam preparation. One of the apps that became very successful was an agricultural app that provided weather forecasts and updates on the market prices for agricultural products in nearby cities where the farmers could potentially sell their products. By using this app, the farmers no longer had to carry their products long distances without knowing what the prices would be at their destination. It saved the farmers time and money, and gave them the opportunity to sell their products when and where market prices were higher. In the words of one of the managers,

'For these people, whose income is about $\$ 100-120$ per month, parting with a dollar or two a month is a big deal. So what was a pleasant surprise was their willingness to carry 
on with this service [agricultural app] month after month. It proved that the service had benefit to them, in that it brought information directly to them - they didn't have to go out and search for the information, they didn't have to spend a lot of time and money or go into the local town to get the information.'

After developing the requested apps, Mobiles for All asked the NGOs to educate people on how to use the mobile phones and apps. This collaboration with the NGOs was quite crucial, as the company did not have the required resources in dispersed local areas to build awareness and sell its product/service itself. According to one of the managers of Mobiles for All,

'NGOs can help us in implementing a programme on the ground because we will never claim to be the best people to implement social programmes because that's not where our expertise lies.'

\subsection{Home Appliances}

Home Appliances is based in Europe. The company operates in more than 60 countries, offering a variety of products such as consumer electronics, kitchen appliances, personal care and healthcare.

In 2005, the company noticed that selling its products in developed countries was becoming difficult, and it was failing to reach four billion lower-income people. In order to develop new ideas for a product/service that could address the needs of these people, the company organised an event comprising 275 managers from Home Appliances worldwide, as 
well as some of the leading NGOs at the BoP. The intention was to promote fresh thinking, and the envisioning of products the company could produce that would improve quality of life at the BoP. Out of 80 suggested solutions, one of the prominent ideas was related to the health of poor people. Since many people at the BoP still cooked indoors with biomass fuels (e.g. wood or dung), respiratory illnesses were quite common among them.

To develop a cheap stove that would not produce smoke, Home Appliances asked NGOs to collaborate with it to conduct a survey at the BoP. The aim of this survey was to gain insight into the culinary habits of rural people in India and their purchasing power, as well as local production and distribution channels. Based on this information, the company would need to develop a stove that was cheap and simple to use, while reducing indoor pollution. The necessity of developing a new product and devising a different business model was reflected by one of the respondents:

'We had to look beyond traditional strategies and develop new strategies to learn about customer needs, product design and innovation in these $[\mathrm{BoP}]$ markets. The significantly lower purchasing power of these populations required new innovative strategies.'

The research conducted by the NGOs and Home Appliances demonstrated the importance of offering a very cheap product. As a result, the company decided to design a smokeless stove and donate the design to local entrepreneurs and NGOs for production and distribution.

It should be pointed out that, although Home Appliances found that it would be unable to earn a profit from the smokeless stove, it was able to gain access to the BoP market through the 
design of the stove, learn about this market's specific needs and, as a result, adapt/develop other products for it. This was illustrated by one of the company's top managers:

'It is also very beneficial for us...it develops brand equity and trust.... It also shows us new ways of co-creating value through cooperation with "unconventional" partners such as NGOs, local entrepreneurs and self-help group women.'

\section{Findings}

In this research, we have attempted to understand entry of MNCs into the BoP from the creation view of opportunities. The findings of this research have revealed several factors contributing to understanding the creation perspective of opportunities at the BoP within an ANT framework. Here we summarise what can be inferred from the activities of our case companies in relation to each of the factors of agency, process and opportunity development.

\subsection{Agency}

\subsubsection{Necessity of involvement of beneficiary stakeholders}

The findings of this research show that, at the BoP, MNCs will not generally be able to enter this market on their own. All of the company cases involved multiple stakeholders such as the BoP communities, NGOs and local entrepreneurs, playing a role in the entrepreneurship process. The main reason these entities were invited to get involved was related to the necessity of ensuring the 4As. 
Engagement of the BoP communities helped the MNCs to learn about their exact needs and consequently to offer a more affordable product. In addition, since the communities have been involved in the product development process, they were more prone to purchase the product.

The involvement of NGOs and local entrepreneurs also contributed to the 4As. The NGOs helped the MNCs to learn about the unmet needs of the BoP people by sharing their knowledge and experience of working with the poor, as well as by asking the communities to collaborate with the MNCs (e.g., in the case of Home Appliances and Mobiles for All).

Some NGOs also helped MNCs to come up with the right ideas with the potential to address the needs of the BoP people. Home Appliances, for example, started by inviting the leading NGOs to help it understand how it could use its own capabilities to solve the social problems at the BoP. In the case of Mobiles for All, NGOs raised the potential of developing a mobile app to address social problems. Collaboration with NGOs ensured that these MNCs developed the right products that were affordable and acceptable to these stakeholders.

It also enabled the MNCs to benefit from the NGOs' local resources and networks in different rural areas. In the case of Home Appliances, NGOs carried out a door-to-door survey about the cooking habits of rural households. Home Appliances then donated the design of the smokeless stove to local entrepreneurs and NGOs who produced and distributed the product. FMCG Co. gained access to NGOs' networks of women in self-help groups. Access to these widespread networks allowed FMCG Co. to develop a relatively cheap distribution channel in India's rural areas. If these MNCs had wanted to employ their own resources, it would have cost 
them much more money and time, and the affordability of their products might have been compromised.

The involvement of the NGOs also contributed to the building of awareness about the products and their advantages. Mobiles for All benefited from its collaboration with NGOs who taught people how to use its mobile phone and apps. NGOs also educated people about the importance of hygiene, which helped FMCG Co. to sell its products much more easily.

It should be noted that, in addition to human actors, non-human actors such as the products of the MNCs were quite critical to the successful creation of opportunities at the BoP. None of the company cases were able to employ their existing products in this market. Instead, they had to adapt/develop new products and processes to suit the BoP conditions.

\subsection{Process}

\subsubsection{Continuous modification of business model to ensure the 4As}

First, it should be noted that none of the company cases were able to use their own existing business models at the BoP. In addition, none of the company cases had a clear idea of the business model that would be successful at the BoP. When they started targeting the BoP, they had to learn and co-create their new business models in collaboration with other agents until they were sure that the BoP people were aware of the product and that the product was affordable, acceptable and available.

The interviews indicate how the activities of the MNCs went in new directions as they learnt about the needs of the BoP people. In the case of FMCG Co., the company started with 
several strategies, each of which proved inadequate and forced it to incorporate another strategy modification in their business model (e.g., changing its marketing and advertising strategy; changing its distribution channel; building awareness about the products). Thus, evaluation and exploitation formed an ongoing process until the company was able to sell its products to this market. Similarly, in the case of Mobiles for All, the company developed an affordable handset but people were still not initially willing to pay for it. The company thus had to revise its business model and invite micro-finance NGOs to offer loans to help the BoP people to afford its product. Still, this initiative was inadequate and the company learned that it had to educate the BoP people about the advantages and benefits mobile phones could offer them. In fact, the pursuit of opportunities led to several modifications to the business model before the best solution was found.

\subsection{Opportunity development}

\subsubsection{Identifying and addressing the specific real needs of the BoP people}

The findings of this research illustrate that opportunity development at the BoP should start with learning about the specific needs of the BoP people. It is very important that MNCs identify the exact products and services that the BoP people need, and to which poor people will be happy to allocate part of their limited income. While, in developed countries, MNCs may incorporate into their products additional features that customers may not need, at the BoP, customers are very sensitive to the price of a product. As a result, MNCs should offer products that address only those needs that have been identified (features, size, etc.). Mobiles for All had to simplify its handset in order to make it affordable and acceptable to the poor. Home Appliances noticed that 
respiratory illness was very common among rural people and that, if it could develop a product to solve this problem, it would be welcomed by the poor.

\subsubsection{Improving the quality of the BoP people's lives}

The findings of this research have revealed that, as part of opportunity development, MNCs should consider how the products they offer can contribute to bringing people at the BoP out of poverty and enhancing the quality of their lives. MNCs should develop solutions that increase the disposable income of the BoP people by either reducing their costs or increasing their incomes. FMCG Co. and Home Appliances are reducing the incidence of diarrhoea and respiratory illness respectively, allowing the poor to avoid spending money on treatment; the agriculture app of Mobiles for All is also reducing the BoP people's living costs, allowing them to avoid having to travel long distances to find out the market prices of the products they wish to sell. These MNCs have also attempted to increase the income of the BoP people by creating job (FMCG Co.) and entrepreneurship (Home Appliances and Mobiles for All) opportunities for them.

\subsubsection{Not rushing into earning a profit}

As part of their opportunity development process, MNCs should accept that they may not earn money from the BoP market immediately. The findings of this research suggest that, because of the dominant poverty in this market, MNCs need to be patient and pursue long-term profitability. 
The company cases in this research had to offer low-priced products with very marginal or even no profit. Home Appliances, for example, had to start with a business model that did not generate any profit for the firm in the short term. However, the company is hoping to learn from its experience and apply its knowledge to develop other products for this market or even its mainstream market in the future. In the case of FMCG Co., it took a long time for the company to make its business model profitable. As one of the interviewees from this firm commented:

'If a company was to start tomorrow and say "I want to do this in rural India", it would take a long time for it to be profitable and this is exactly what we are witnessing right now.'

\section{Discussion}

While the dominant view in the entrepreneurship literature centres around opportunity discovery (Shane 2003, Kirzner 1979, 1997), this study corroborates the idea that, at the BoP, MNCs have to pursue the creation approach towards opportunities (Fletcher 2006, Gaddefors 2005, Korsgaard 2013). A summary of the findings of this research based on the ANT and in relation to the agents, process and opportunity development is presented in Table 2.

*** Insert Table 2 about here*** 
In contrast to the discovery perspective that relies on an alert individual entrepreneur to recognise opportunities (Shane 2003), and consistent with the ANT interpretation of the creation approach, the findings of this research illustrate that at the BoP, multiple stakeholders and beneficiaries should collaborate together in order to develop opportunities, corroborating prior studies (Gaddefors 2005, Johannisson, Ramírez-Pasillas, and Karlsson 2002). This research thus endorses the social constructionism view of opportunities and emphasises that opportunities are not developed in the mind of the entrepreneur but during the interaction of the entrepreneur with its network, confirming social and relational aspects of the entrepreneurship (Fletcher 2006, Bjerke and Karlsson 2013). It also validates the collective entrepreneurship literature emphasising the necessity of the involvement of different actors in the process of entrepreneurship (Johannisson 1998, Johannisson and Nilsson 1989, Holmquist 2003, Lindgren and Packendorff 2003, Johannisson 2011).

In addition to the MNCs and their modified products, the key agents that played a role were NGOs, the BoP communities and local entrepreneurs, as outlined in Table 2. Without the contributions of each of these actors, the companies would not have been able to ensure the 4As at the BoP. This is consistent with the findings of other scholars highlighting the importance of the involvement of NGOs and low-income people for successful entry into this market (e.g., Perez-Aleman and Sandilands 2008, Seelos and Mair 2007, Rashid and Rahman 2009, London and Hart 2004). The participation of NGOs and the BoP people in the product development process enabled these MNCs to learn about the specific needs of the people in this market, allowed them to build awareness of their products, enhanced the acceptability of the products, and facilitated their distribution through these agents (Anderson and Billou 2007). According to 
prior studies, establishing a network of such actors can improve the innovation capabilities of MNCs (Gellynck, Vermeire, and Viaene 2007), provide access to resources and knowledge (Witt 2004, Bhagavatula et al. 2010, Tolstoy 2010) that they may lack at the BoP, and enhance BoP communities' wellbeing (Besser, Miller, and Perkins 2006). The importance of the involvement of the $\mathrm{BoP}$ communities in this process also supports the findings suggesting that the BoP community can play an influential role in the execution and outcome of any entrepreneurial activity there (Hindle 2010, Johnstone and Lionais 2004).

Contrary to the discovery approach, the pursuit of opportunities at the BoP was not linear and did not follow the traditional three stages of opportunity discovery, evaluation and exploitation (e.g., Shane 2003, Eckhardt and Shane 2003). Instead, it was an intertwined process and these stages co-existed and were not separable (Fletcher 2007). None of the company cases started with the opportunity discovery and evaluation stage, as the low incomes of the BoP population would have prevented them from being considered as opportunities. Instead, all of the companies learned about the needs of the BoP and how they could contribute towards addressing those needs. In line with the findings of London and Hart (2004), all of the company cases had to reinvent their business models, change their products and modify their processes in such a way as to overcome the disadvantaged conditions of the $\mathrm{BoP}$. The product/process development was iterative and continued until the companies had developed situations in which the BoP people were happy to pay for their products. This resonates with the argument of Weick (1979) suggesting that agents should take action, look at the reactions of their customers, and then adjust their products accordingly. For example, in the case of Mobiles for All, the company was not successful by just offering a simple and affordable handset; it had to come up with the idea of 
micro-finance for the purchase of its products, and even offer mobile apps to enhance the poor people's income.

Although the discovery view suggests that opportunities have subjective existence prior to the entrepreneurship process (Shane 2003), the findings of this research illustrate that at the BoP opportunities are not out there and need to be developed. When developing opportunities, it is crucial that MNCs do not just focus on their own profits. Instead, the company cases had to consider the 'real needs' of the BoP people and how their products/processes could improve the quality of their lives. This also corroborates the findings suggesting that the endeavours of companies at the BoP should centre around mutual value creation (London, Anupindi, and Sheth 2010, Prasad and Ganvir 2005). Corporations have also been advised to pursue business models that incorporate the BoP people as producers and entrepreneurs (London and Hart 2010). Undoubtedly, all these initiatives of MNCs at the BoP have not only developed opportunities for the companies but have also led to community development (Spilling 2011).

It should also be mentioned that it is through this mutual value creation that MNCs have been successful in mobilising different actors such as NGOs and BoP communities. This is also consistent with the proposition of Porter and Kramer (2011) arguing that corporations' success would benefit from aligning companies' activities with social betterment. The necessity of aligning corporations' values with the social values that NGOs pursue has also been emphasised for a successful collaboration (Waddell 2000, 1999, Dahan et al. 2010).

Finally, the last point that ensures successful opportunity development is related to the importance of adopting a long-term orientation towards earning a profit in this market. While 
prior research points out that there are fortunes to be made at the BoP (Hammond et al. 2007, Prahalad 2010), the findings of this research illustrate that, because of the nature of the opportunity development there, profitability may not occur immediately. While companies should invest in enhancing the disposable income of the poor, they should be aware that coming out of poverty takes time and that they will be unlikely to jump straight into earning high profits from this market.

\section{Conclusion}

This research aimed to reveal how MNCs can enter the BoP market. We adopted the creation perspective of opportunities and employed the ANT to shed light on the actors, processes and opportunity development in this market. A summary of the findings of this research is presented in Figure 2.

***Insert Figure 2 about here***

The figure illustrates that successful entry into the BoP market requires the involvement of multiple beneficiaries. In particular, gaining the support of NGOs (London and Hart 2004, Reficco and Márquez 2012, Dahan et al. 2010) and the involvement of the BoP population can guarantee subsequent success (Dahan et al. 2010, Hindle 2010). Second, we have illuminated the point that MNCs should engage in an iterative process and redefine their business models several times in order that they suit the BoP conditions. In this process, companies will benefit from the involvement of different agents who can contribute to affordability, acceptability, availability 
and awareness. Third, corporations have to invest in developing the opportunities. Despite the huge market size, corporations need to create conditions in which it will make sense for these low-income people to spend their limited funds on the corporations' products. The findings of this research show that companies can achieve this by incorporating the real needs of the poor into their plans. In addition, when developing products and services, companies should not only address these needs but also offer solutions that increase the disposable income of poor people. Finally, in the opportunity development process, MNCs should be open to the adoption of business models that may not lead to immediate profits.

This research makes several contributions. First, it adds to the entrepreneurship literature, by investigating opportunity in the context of large and established corporations (Zahra 1996, Kellermanns and Eddleston 2006, Ghauri, Hadjikhani, and Johanson 2005). Second, the findings of this research authorise the process theories of entrepreneurship (Steyaert 2007) by highlighting the necessity of pursuing the creation perspective of opportunities at the BoP market (Sanz-Velasco 2006, Korsgaard 2013). This is a totally different understanding from the dominant discovery view in the entrepreneurship literature (Kirzner 1997, 1973, Shane and Venkataraman 2000, Shane 2003). Third, this research provides new empirical insights into ANT interpretation of the creation perspective (Korsgaard 2011). Specifically, based on the ANT, we have revealed that at the $\mathrm{BoP}$ opportunities are constructed in a relational exchange and through a non-linear process (Fletcher 2006, Bjerke and Karlsson 2013, Schindehutte and Morris 2009). In this vein, this research offers empirical insights into the proposition of Fletcher (2006, p. 436) who explains that in the social constructivism view, "the enquirer moves beyond an examination of individual opportunity-seeking processes to consideration of the relationality between 
peoples' actions and their cultural, societal, economic and political situational context". Finally, the findings of this research contribute to the collective entrepreneurship literature by pinpointing the reality of distributed agency in the entrepreneurship process (Johannisson 1998, Johannisson and Nilsson 1989, Holmquist 2003, Lindgren and Packendorff 2003, Johannisson 2011, Bjerke and Karlsson 2013).

This study also has some managerial implications as it illuminates how MNCs' managers can successfully enter the BoP market. First, managers should seek the collaboration of other agents in their network and expand their network to include non-traditional partners when required (Hadjikhani, Lee, and Ghauri 2008, London and Hart 2004). Second, they should learn that, at the BoP, defining a business model is a continuous, recurring process. Finally, business managers should engage in a process of transformation and development of opportunities by serving the key needs of the BoP people and developing solutions that will bring them out of poverty and produce long-term profitability.

This research is not without limitations. Although it was originally based on eight cases, three of which are presented in this paper, it is limited in its generalisability. It is only based on the ANT interpretation of the creation perspective and is mainly built upon the MNCs' viewpoint. Future studies could employ other theoretical perspectives in this area to illuminate other aspects, and interview different actors to provide a more comprehensive picture of the phenomenon. Future studies could also carry out quantitative research to test the findings of this research. 
Acknowledgements

The authors gratefully acknowledge the substantial advice, comments and insights offered by Professor Alistair Anderson and the anonymous reviewers. 
References:

Akrich, Madeleine, Michel Callon, and Bruno Latour. 2002. "The key to success in innovation part I: The art of interessement." International Journal of Innovation Management 6 (2):187-206.

Alvarez, Sharon A., and Simon C. Parker. 2009. "New firm organization and the emergence of control rights: A Bayesian approach." Academy of Management Review 34 (2):209-227.

Alvarez, Sharon A., and Jay B. Barney. 2007. "Discovery and creation: Alternative theories of entrepreneurial action." Strategic Entrepreneurship Journal 1 (2):11-26.

Alvarez, Sharon A., Jay B. Barney, and Philip Anderson. 2013. "Forming and Exploiting Opportunities: The Implications of Discovery and Creation Processes for Entrepreneurial and Organizational Research." Organization Science 24 (1):301-317. doi: 10.1287/orsc.1110.0727.

Anderson, Alistair R., and Sarah L. Jack. 2002. "The articulation of social capital in entrepreneurial networks: A glue or a lubricant?" Entrepreneurship \& Regional Development 14 (3):193-210. doi: 10.1080/08985620110112079.

Anderson, Jamie, and Niels Billou. 2007. "Serving the world's poor: Innovation at the base of the economic pyramid." Journal of Business Strategy 28 (2):14-21.

Baker, Ted, and Reed E. Nelson. 2005. "Creating Something from Nothing: Resource Construction through Entrepreneurial Bricolage." Administrative Science Quarterly 50 (3):329-366.

Besser, Terry L., Nancy Miller, and Robert K. Perkins. 2006. "For the greater good: business networks and business social responsibility to communities." Entrepreneurship \& Regional Development 18 (4):321-339.

Bhagavatula, Suresh, Tom Elfring, Aad van Tilburg, and Gerhard G. van de Bunt. 2010. "How social and human capital influence opportunity recognition and resource mobilization in India's handloom industry." Journal of Business Venturing 25 (3):245-260.

Bjerke, Björn, and Mathias Karlsson. 2013. "Why are some people behaving or acting entrepreneurially more than others? : Looking at opportunities as part of entrepreneurial 
behavior or action in more than one way." Journal of Business and Economics 4:465474.

Bryman, Alan, and Emma Bell. 2007. Business Research Methods. 2nd ed. Oxford: Oxford University Press.

Burr, Vivien. 2003. Social constructionism. 2nd ed. London: Routledge.

Butler, John, and Gary Hansen. 1991. "Network evolution, entrepreneurial success, and regional development." Entrepreneurship \& Regional Development 3 (1):1-16.

Chabaud, Didier, Alain Fayolle, Sarah Jack, and Wadid Lamine. 2012. "Entrepreneurial Process and Social Networks: A Dynamic Perspective." Entrepreneurship \& Regional Development 24 (7/8):729-732. doi: 10.1080/08985626.2012.726508.

Chia, Robert. 1995. "From Modern to Postmodern Organizational Analysis." Organization Studies (Walter de Gruyter GmbH \& Co. KG.) 16 (4):579.

Creswell, John W. 2007. Qualitative Inquiry \& Research Design: Choosing Among Five Approaches. 2nd ed. Thousand Oaks, CA: Sage.

Dahan, Nicolas M., Jonathan P. Doh, Jennifer Oetzel, and Michael Yaziji. 2010. "CorporateNGO Collaboration: Co-creating New Business Models for Developing Markets." Long Range Planning 43 (2-3):326-342.

Dutta, Dev K., and Mary M. Crossan. 2005. "The Nature of Entrepreneurial Opportunities: Understanding the Process Using the 4I Organizational Learning Framework." Entrepreneurship: Theory \& Practice 29 (4):425-449.

Eckhardt, Jonathan T., and Scott A. Shane. 2003. "Opportunities and Entrepreneurship." Journal of Management 29 (3):333-349.

Eisenhardt, Kathleen M. 1989. "Building theories from case study research." Academy of Management Review 14 (4):532-550.

Eisenhardt, Kathleen M., and Melissa E. Graebner. 2007. "Theory buidling from cases: Opportunities and challenges." Academy of Management Journal 50 (1):25-32.

Fletcher, Denise. 2007. "'Toy Story': the narrative world of entrepreneurship and the creation of interpretive communities." Journal of Business Venturing 22 (5):649-672. 
Fletcher, Denise E. 2006. "Entrepreneurial processes and the social construction of opportunity." Entrepreneurship \& Regional Development 18 (5):421-440.

Flick, Uwe. 2009. An Introduction to Qualitative Research. 4th ed. London: SAGE Publications.

Gaddefors, Johan. 2005. "Creating context - entrepreneurial opportunities in a consumer market setting." Journal of Enterprising Culture 13 (3):199-224.

Garud, Raghu, and Peter Karnøe. 2001. Path Dependence and Creation. Mahwah, NJ: Lawerence Erlbaum Associates.

Gellynck, Xavier, Bert Vermeire, and Jacques Viaene. 2007. "Innovation in food firms: Contribution of regional networks within the international business context." Entrepreneurship \& Regional Development 19 (3):209-226.

Gerring, John. 2007. Case Study Research: Principles and Practices. Cambridge: Cambridge University Press.

Ghauri, Pervez N. 2004. "Designing and conducting case studies in international business research." In Handbook of qualitative research methods for international business, edited by Rebecca Marschan-Piekkari and Catherine Welch, 107-124. Cheltenham, UK: Edward Elgar.

Ghauri, Pervez N., and Kjell Gronhaug. 2010. Research methods in business studies: A practical guide. 4th ed. Harlow: England: Financial Times/ Prentice Hall.

Ghauri, Pervez N., Amjad Hadjikhani, and Jan Johanson, eds. 2005. Managing opportunity development in business networks. New York: Palgrave MacMillan.

Gummesson, Evert. 2003. "All research is interpretive!" Journal of Business \& Industrial Marketing 18 (6-7):482-492.

Hadjikhani, Amjad, Joong-Woo Lee, and Pervez N. Ghauri. 2008. "Network view of MNCs' socio-political behavior." Journal of Business Research 61 (9):912-924. doi: 10.1016/j.jbusres.2007.10.001.

Hair, Joseph F., Arthur H. Moeny, Philip Samouel, and Mike Page. 2007. Research methods for business. Sussex, England: John Wiley \& Sons, Ltd. 
Halme, Minna, Sara Lindeman, and Paula Linna. 2012. "Innovation for Inclusive Business: Intrapreneurial Bricolage in Multinational Corporations." Journal of Management Studies 49 (4):743-784. doi: 10.1111/j.1467-6486.2012.01045.x.

Hammond, Allen L., William J. Kramer, Julia Tran, Rob Katz, and Courtland Walker. 2007. The Next 4 billion: Market size and business strategy at the base of the pyramid. Washington, DC: World Resources Institute, International Finance Corporation, The World Bank.

Hart, Stuart L. 2005. Capitalism at the crossroads: The unlimited business opportunities in solving the world's most difficult problems. Upper Saddle River, NJ.

Hindle, Kevin. 2010. "How Community Context Affects Entrepreneurial Process: A Diagnostic Framework." Entrepreneurship and Regional Development 22 (7-8):599-647. doi: http://www.tandfonline.com/loi/tepn20.

Holmquist, Carin. 2003. "Is the medium really the message? Moving perspective from the entrepreneurial actor to the entrepreneurial action." In New Movements In Entrepreneurship, edited by Chris Steyaert and Daniel Hjorth, 73-85. Cheltenham, UK: Edward Elgard Publishing Limited.

Johannisson, Bengt. 2011. "Towards a practice theory of entrepreneuring." Small Business Economics 36 (2):135-150. doi: 10.1007/s11187-009-9212-8.

Johannisson, Bengt 1998. Entrepreneurship as a collective phenomenon. Lyon, France: RENT XII.

Johannisson, Bengt, and Anders Nilsson. 1989. "Community entrepreneurs: networking for local development." Entrepreneurship \& Regional Development 1 (1):3-19.

Johannisson, Bengt, Marcela Ramírez-Pasillas, and Gösta Karlsson. 2002. "The institutional embeddedness of local inter-firm networks: A leverage for business creation." Entrepreneurship \& Regional Development $14 \quad$ (4):297-315. doi: $10.1080 / 08985620210142020$.

Johnstone, Harvey, and Doug Lionais. 2004. "Depleted communities and community business entrepreneurship: revaluing space through place." Entrepreneurship \& Regional Development 16 (3):217-233. 
Kellermanns, Franz W., and Kimberly A. Eddleston. 2006. "Corporate Entrepreneurship in Family Firms: A Family Perspective." Entrepreneurship: Theory \& Practice 30 (6):809830. doi: 10.1111/j.1540-6520.2006.00153.x.

Kirzner, Israel M. 1973. Competition and Entrepreneurship. Chicago, IL: University of Chicago Press.

Kirzner, Israel M. 1979. Perception, Opportunity and Profit. Chicago, IL: University of Chicago Press.

Kirzner, Israel M. 1997. "Entrepreneurial Discovery and the Competitive Market Process: An Austrian Approach." Journal of Economic Literature 35 (1):60-85.

Korsgaard, Steffen. 2011. "Entrepreneurship as translation: Understanding entrepreneurial opportunities through actor-network theory." Entrepreneurship \& Regional Development 23 (7/8):661-680. doi: 10.1080/08985626.2010.546432.

Korsgaard, Steffen. 2013. "It's really out there: a review of the critique of the discovery view of opportunities." International Journal of Entrepreneurial Behaviour \& Research 19 (2):130-148.

Latour, Bruno. 1987. Science in action: How to follow scientists and engineers through society. Cambridge, MA: Harvard University Press.

Latour, Bruno. 2005. Reassembling the social: An Introduction to Actor-Network-Theory. Oxford: Oxford University Press.

Law, John. 1999. "After ANT: Complexity, naming and topology." In Actor-network theory and after, edited by John Law and John Hassard, 1-14. Boston, MA: Blackwell.

Lechner, Christian, and Michael Dowling. 2003. "Firm networks: External relationships as sources for the growth and competitiveness of entrepreneurial firms." Entrepreneurship \& Regional Development 15 (1):1-26.

Lindgren, Monica, and Johann Packendorff. 2003. "A Project-based View of Entrepreneurship: Towards Action-orientation, Seriality and Collectivity " In New Movements In Entrepreneurship, edited by Chris Steyaert and Daniel Hjorth, 86-102. Cheltenham, UK: Edward Elgard Publishing Limited. 
London, Ted, Ravi Anupindi, and Sateen Sheth. 2010. "Creating mutual value: Lessons learned from ventures serving base of the pyramid producers." Journal of Business Research 63 (6):582-594.

London, Ted, and Stuart L. Hart. 2004. "Reinventing strategies for emerging markets: Beyond the transnational model." Journal of International Business Studies 35 (5):350-370.

London, Ted, and Stuart L. Hart. 2010. Next Generation Business Strategies for the Base of the Pyramid. Wharton: Wharton School Publishing.

Mosakowski, Elaine. 1997. "Strategy Making Under Causal Ambiguity: Conceptual Issues and Empirical Evidence." Organization Science 8 (4):414-442.

Perez-Aleman, Paola, and Marion Sandilands. 2008. "Building Value at the Top and the Bottom of the Global Supply Chain: MNC-NGO Partnerships." California Management Review $51(1): 24-49$.

Porter, Michael E., and Mark R. Kramer. 2011. "Creating shared value." Harvard Business Review 89 (1/2):62-77.

Prahalad, C. K. 2010. The fortune at the bottom of the pyramid: Eradicating poverty through profits. 4th ed. Upper Saddle River, New Jersey: Wharton School Publishing.

Prasad, V. C. S., and Vivek Ganvir. 2005. "Study of the principles of innovation for the BOP consumer - the case of a rural water filter." International Journal of Innovation and Technology Management 2 (4):349-366.

Rashid, Ahmed T., and Mizan Rahman. 2009. "Making profit to solve development problems: the case of Telenor AS and the Village Phone Programme in Bangladesh." Journal of Marketing Management 25 (9/10):1049-1060.

Reficco, Ezequiel, and Patricia Márquez. 2012. "Inclusive Networks for Building BOP Markets." Business \& Society 51 (3):512-556. doi: 10.1177/0007650309332353.

Sanz-Velasco, Stefan A. 2006. "Opportunity development as a learning process for entrepreneurs." International Journal of Entrepreneurial Behaviour \& Research 12 (5):251-271. 
Sarason, Yolanda, Tom Dean, and Jesse F. Dillard. 2006. "Entrepreneurship as the nexus of individual and opportunity: A structuration view." Journal of Business Venturing 21 (3):286-305.

Sarason, Yolanda, Jesse F. Dillard, and Tom Dean. 2010. "How can we know the dancer from the dance?: Reply to "Entrepreneurship as the structuration of individual and opportunity: A response using a critical realist perspective". (Mole and Mole, 2008)." Journal of $\begin{array}{llll}\text { Business } \quad 25 & \text { (2):238-243. doi: }\end{array}$ http://dx.doi.org/10.1016/j.jbusvent.2008.06.003.

Sarasvathy, Saras D. 2008. Effectuation: Elements of entrepreneurial expertise. Cheltenham: Edward Elgar.

Schindehutte, Minet, and Michael H. Morris. 2009. "Advancing Strategic Entrepreneurship Research: The Role of Complexity Science in Shifting the Paradigm." Entrepreneurship: Theory \& Practice 33 (1):241-276. doi: 10.1111/j.1540-6520.2008.00288.x.

Schuster, Tassilo, and Dirk Holtbrügge. 2012. "Market entry of multinational companies in markets at the bottom of the pyramid: A learning perspective." International Business Review 21 (5):817-830.

Seelos, Christian, and Johanna Mair. 2007. "Profitable business models and market creation in the context of deep poverty: A strategic view." Academy of Management Perspectives 21 (4):49-63.

Shane, Scott. 2003. A general theory of entrepreneurship: The individual-opportunity nexus. Edited by Sabkarab Venkataraman, New horizons in entrepreneurship. Cheltenham, UK: Edward Elgar.

Shane, Scott, and Sankaran Venkataraman. 2000. "The promise of entrepreneurship as a field of research." Academy of Management Review 25 (1):217-226.

Silverman, David. 2010. Doing qualitative research. 3rd ed. London: Sage.

Spilling, Olav R. 2011. "Mobilising the entrepreneurial potential in local community development." Entrepreneurship \& Regional Development 23 (1/2):23-35. doi: 10.1080/08985626.2011.540406. 
Steyaert, Chris. 2007. "'Entrepreneuring' as a conceptual attractor? A review of process theories in 20 years of entrepreneurship studies." Entrepreneurship \& Regional Development 19 (6):453-477. doi: 10.1080/08985620701671759.

Swanborn, Peter G. 2012. Case study research. London: SAGE Publications Inc.

The World Bank. 2008. World development indicators: Poverty data a supplement to World Development Indicators 2008. International Bank for Reconstruction and Development.

Tolstoy, Daniel. 2010. "Network development and knowledge creation within the foreign market: A study of international entrepreneurial firms." Entrepreneurship \& Regional Development 22 (5):379-402. doi: 10.1080/08985620903168273.

UNDP. 2008. Creating value for all: Strategies for doing business with the poor. New York: United Nations Development Programme.

Van De Ven, A.H. 2007. Engaged scholarship. Oxford: Oxford University Press.

Verbeke, Alain, James J. Chrisman, and Wenlong Yuan. 2007. "A Note on Strategic Renewal and Corporate Venturing in the Subsidiaries of Multinational Enterprises." Entrepreneurship: Theory \& Practice 31 (4):585-600.

Waddell, Steve. 1999. Business-government-nonprofit collaborations as agents for social innovation and learning. Boston: Organizational Futures.

Waddell, Steve. 2000. "A "Win-Win” Role of Civil Society in Business Strategy." Journal for Nonprofit Management 4 (1):24-43.

Webb, Justin W., Geoffrey M. Kistruck, R. Duane Ireland, and Jr David J. Ketchen. 2010. "The Entrepreneurship Process in Base of the Pyramid Markets: The Case of Multinational Enterprise/Nongovernment Organization Alliances." Entrepreneurship: Theory \& Practice 34 (3):555-581.

Weick, Karl E. 1979. The social psychology of organizing. 2nd ed. New York: Random House.

Williams, Nick, and Colin C. Williams. 2012. "Evaluating the socio-spatial contingency of entrepreneurial motivations: A case study of English deprived urban neighbourhoods." Entrepreneurship \& Regional Development 24 (7/8):661-684. doi: 10.1080/08985626.2012.710259. 
Witt, Peter. 2004. "Entrepreneurs' networks and the success of start-ups." Entrepreneurship \& Regional Development 16 (5):391-412. doi: 10.1080/0898562042000188423.

Wood, Matthew S., and William McKinley. 2010. "The production of entrepreneurial opportunity: a constructivist perspective." Strategic Entrepreneurship Journal 4 (1):6684.

World Bank, The Water and Sanitation Program, \& The London School of Hygiene and Tropical Medicine, . 2000. Sanitation and hygiene: Unleashing the power of the market. In Draft proposal to forge public-private partnerships in selected developing countries.

Yin, Robert K. 2009. Case study research: Design and methods. 4th ed. Vol. 5, Applied social research methods series. Thousand Oaks: California: Sage Publications.

Yin, Robert K. 2014. Case study research: Design and methods. 5th ed, Applied social research methods series. Thousand Oaks: California: Sage Publications, Inc.

Zahra, Shaker A. 1996. "Governance, ownership, and corporate entrepreneurship: The moderating impact of industry technological opportunities." Academy of Management Journal 39 (6):1713-1735. 
Table 1. Overview of company cases

\begin{tabular}{|l|l|l|}
\hline Company* & Industry & Activities at the BoP in India \\
\hline FMCG Co. & $\begin{array}{l}\text { Fast-moving } \\
\text { consumer goods }\end{array}$ & $\begin{array}{l}\text { FMCG Co. is one of the largest producers of fast- } \\
\text { moving consumer goods in India, with products } \\
\text { such as soap, tea, detergent and shampoo. The } \\
\text { company offers affordable and accessible } \\
\text { products to rural areas to meet the needs of the } \\
\text { poor. }\end{array}$ \\
\hline $\begin{array}{l}\text { Mobiles for } \\
\text { All }\end{array}$ & $\begin{array}{l}\text { Mobile } \\
\text { telecommunications }\end{array}$ \\
\hline $\begin{array}{l}\text { Hobiles for All produces affordable handsets and } \\
\text { has developed several mobile applications (apps) } \\
\text { (e.g. agricultural apps, educational apps) for low- } \\
\text { income people. }\end{array}$ \\
\hline Eppliances & Electronics & $\begin{array}{l}\text { Home Appliances offers consumer electronic } \\
\text { goods, domestic appliances, lighting, medical } \\
\text { systems and medical technology. Built upon its } \\
\text { superior design capabilities, the company has } \\
\text { designed a smokeless stove for the BoP } \\
\text { population. }\end{array}$ \\
\hline
\end{tabular}

*Note: Fake names have been given to the companies for confidentiality purposes. 


\begin{tabular}{|c|c|c|c|}
\hline Company case & Actors & Process & $\begin{array}{l}\text { Opportunity } \\
\text { development }\end{array}$ \\
\hline FMCG Co. & $\begin{array}{l}\text {-FMCG Co. } \\
\text {-Affordable and } \\
\text { available products } \\
\text {-NGOs (introducing } \\
\text { thousands of low- } \\
\text { income women) } \\
\text {-Low-income women } \\
\text { (sales representatives } \\
\text { and distributors) }\end{array}$ & $\begin{array}{l}\text {-Preliminary } \\
\text { evaluation did not } \\
\text { support opportunity } \\
\text { discovery due to the } \\
\text { lack of disposable } \\
\text { income of the BoP } \\
\text { people } \\
\text {-Different stages of } \\
\text { entrepreneurship } \\
\text { process (discovery, } \\
\text { evaluation and } \\
\text { exploitation) were } \\
\text { continuous and } \\
\text { inseparable: } \\
\text {-Modifying existing } \\
\text { product and offering } \\
\text { cheaper single-serve } \\
\text { sachets } \\
\text {-Modifying } \\
\text { marketing, } \\
\text { advertising } \\
\text { promotion strategy } \\
\text { considering the lack } \\
\text { of TVs and illiteracy: } \\
\text { pictorial messages on } \\
\text { walls, face-to-face } \\
\text { promotion, educating } \\
\text { people about the } \\
\text { importance } \\
\text { hygiene of } \\
\text { washing hands with } \\
\text { soap) of } \\
\text {-Distribution } \\
\text { products by rural } \\
\text { low-income women }\end{array}$ & $\begin{array}{l}\text {-More than } 70 \% \text { of } \\
\text { India's population } \\
\text { live in rural areas and } \\
\text { have low disposable } \\
\text { income } \\
\text {-Addressing the } \\
\text { needs of the BoP } \\
\text { people } \\
\text {-Modification of } \\
\text { product/process to } \\
\text { suit the BoP people's } \\
\text { needs } \\
\text {-Empowerment of } \\
\text { the BoP people } \\
\text {-Improving the } \\
\text { quality of life at the } \\
\text { BoP (e.g., reduction } \\
\text { of the incidence of } \\
\text { diarrhoea) }\end{array}$ \\
\hline Mobiles for All & $\begin{array}{l}\text {-Mobiles for All } \\
\text {-Simple affordable } \\
\text { handsets }\end{array}$ & $\begin{array}{l}\text {-Opportunity } \\
\text { discovery, evaluation } \\
\text { and exploitation were }\end{array}$ & $\begin{array}{l}\text {-Availability of large } \\
\text { market size (low } \\
\text { penetration }\end{array}$ \\
\hline
\end{tabular}




\begin{tabular}{|c|c|c|c|}
\hline & $\begin{array}{l}\text {-Mobile apps } \\
\text {-NGOs (offering } \\
\text { micro-finance) } \\
\text {-BoP communities } \\
\text { (contribution to the } \\
\text { process of mobile } \\
\text { appdevelopment) } \\
\text {-NGOs (suggesting } \\
\text { mobile apps and } \\
\text { educating people } \\
\text { about the use of } \\
\text { mobile apps) }\end{array}$ & $\begin{array}{l}\text { a continuous process. } \\
\text { The company had to } \\
\text { re-evaluate the } \\
\text { opportunity and the } \\
\text { needs of the BoP } \\
\text { people several times } \\
\text { and modify its } \\
\text { business model } \\
\text { accordingly: } \\
\text {-Offering simple, } \\
\text { durable and } \\
\text { affordable handsets } \\
\text { that suit the needs of } \\
\text { the BoP } \\
\text {-Inviting NGOs to } \\
\text { offer micro-finance } \\
\text {-Surveying the needs } \\
\text { of the BoP people in } \\
\text { terms of mobile apps } \\
\text { (through } \\
\text { collaboration with } \\
\text { NGOs) } \\
\text {-Developing apps } \\
\text { that reduce social } \\
\text { problems based on } \\
\text { the request of NGOs } \\
\text {-Adapting marketing, } \\
\text { sales and distribution } \\
\text { based on the BoP } \\
\text { conditions }\end{array}$ & $\begin{array}{l}\text { mobiles in rural areas } \\
\text { of India) } \\
\text {-Educating people } \\
\text { about the role mobile } \\
\text { apps could play in } \\
\text { improving their lives } \\
\text { (through } \\
\text { collaboration with } \\
\text { NGOs) } \\
\text {-Improving the } \\
\text { quality of the BoP } \\
\text { people's lives by } \\
\text { giving them the } \\
\text { opportunity to earn } \\
\text { more money/ } \\
\text { reducing their costs } \\
\text { through mobile apps } \\
\text { (e.g., agricultural } \\
\text { app) }\end{array}$ \\
\hline Home Appliances & $\begin{array}{l}\text {-Home Appliances } \\
\text {-NGOs (developing } \\
\text { ideas to address } \\
\text { social problems) } \\
\text {-Smokeless stove } \\
\text {-NGOs (conducting } \\
\text { survey about the } \\
\text { culinary habits of the } \\
\text { BoP) } \\
\text {-NGOs and local } \\
\text { entrepreneurs (as } \\
\text { manufacturers and } \\
\text { distributors) }\end{array}$ & $\begin{array}{l}\text {-A profitable } \\
\text { opportunity using the } \\
\text { products of the firm } \\
\text { did not exist; the } \\
\text { company had to } \\
\text { involve several } \\
\text { agents and seek their } \\
\text { collaboration to } \\
\text { develop an } \\
\text { opportunity based on, } \\
\text { Home Appliances' } \\
\text { capabilities } \\
\text {-Identification of a } \\
\text { social problem that }\end{array}$ & $\begin{array}{l}\text {-Saturated market in } \\
\text { developed countries } \\
\text { and four billion low- } \\
\text { income people at the } \\
\text { BoP } \\
\text {-Considering the } \\
\text { social problem/ the } \\
\text { real needs of the BoP } \\
\text { people before } \\
\text { designing the product } \\
\text {-Developing } \\
\text { products/processes } \\
\text { that suited the needs } \\
\text { of the BoP }\end{array}$ \\
\hline
\end{tabular}




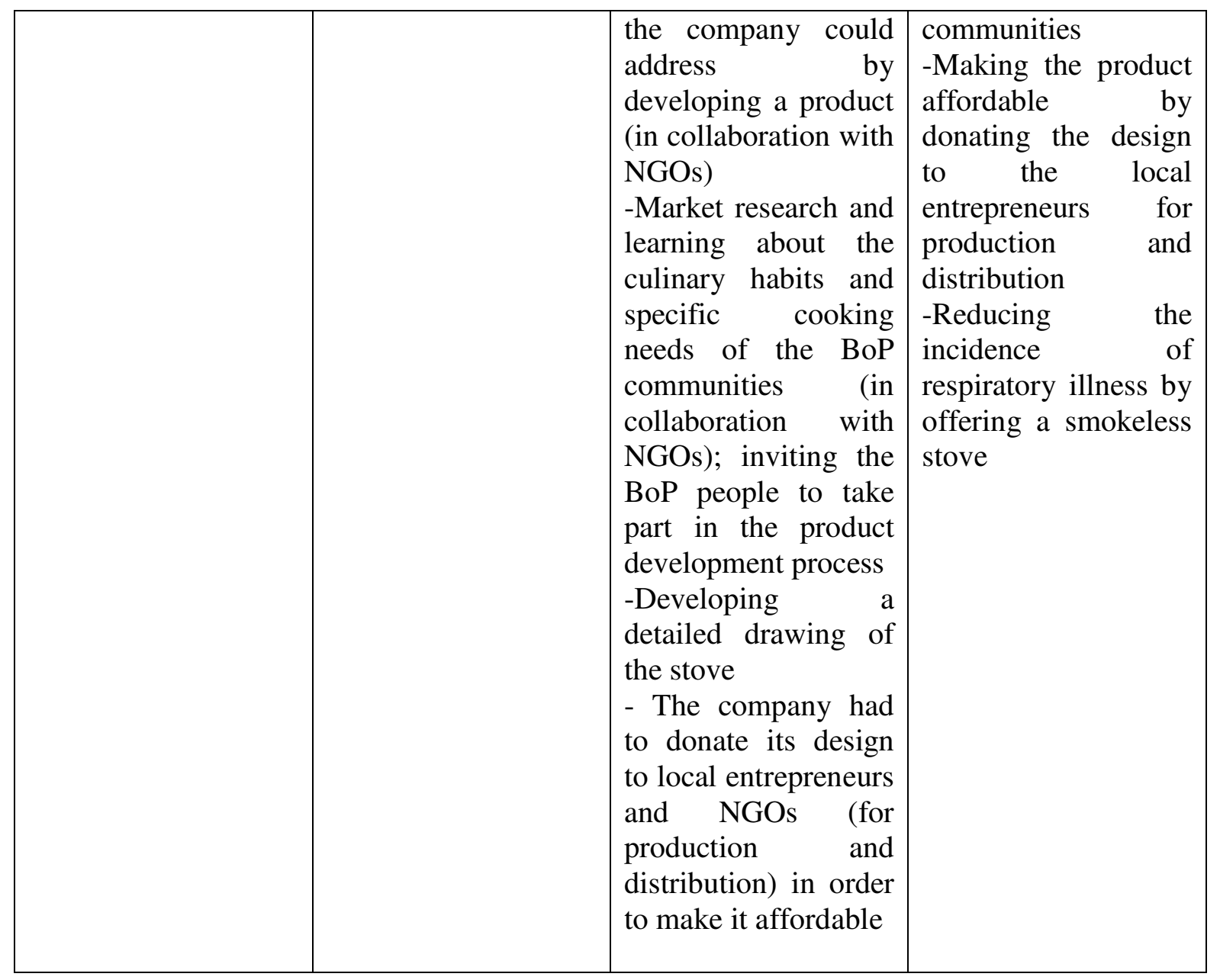




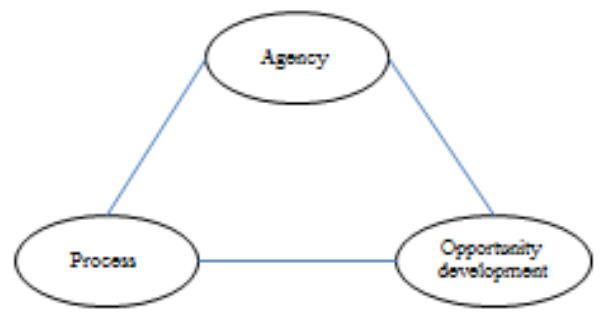

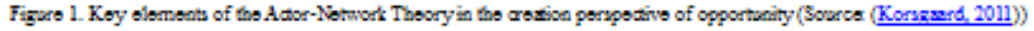




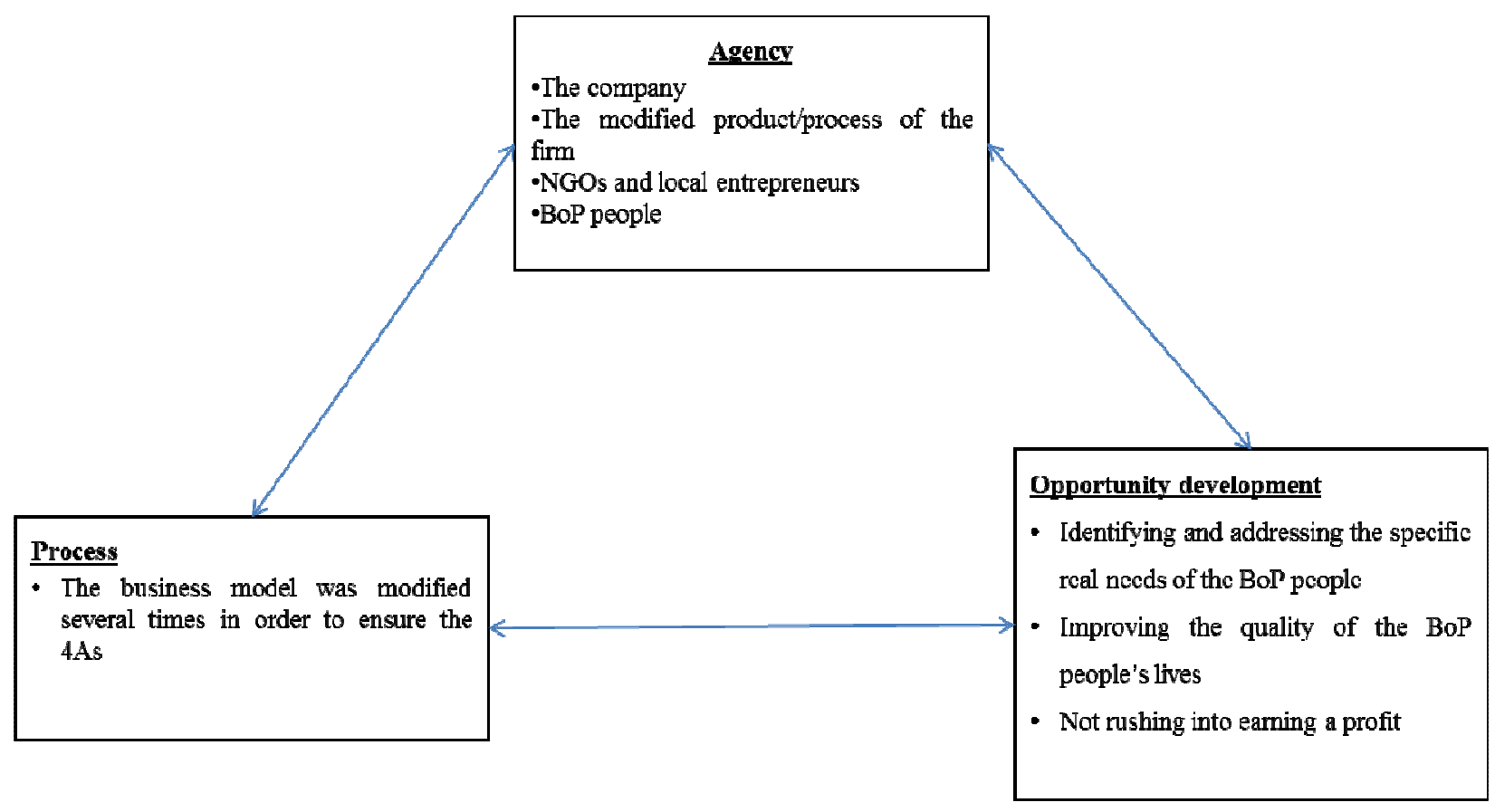

Figure 2. The creation perspective of opportunities at the BoP based on the $\Lambda$ VI framework 